\title{
El món dels microorganismes a sisè de primària
}

\author{
Núria Gaju nuria.gaju@uab.es, Maira Martínez-Alonso i Ingrid Salazar \\ Departament de Genètica i Microbiologia. Facultat de Ciències. Universitat Autònoma de Barcelona \\ Pilar Gorina, Lola Miró i Mercè Saiz \\ CEIP Escola Bellaterra, Cerdanyola
}

Dins del món dels éssers vius hi ha un grup d'organismes invisibles a l'ull humà anomenats microorganismes. D'aquests éssers vius se'n té poca informació, tot i la seva importància en el funcionament del nostre planeta i en les seves múltiples aplicacions. Aquesta manca d'informació ve donada, en part, per la necessitat de tècniques i instrumental específic per a la seva investigació i per a la seva observació. En aquesta experiència volem mostrar la diversitat d'organismes que constitueixen aquest món microbià $i$ presentarlo als nens a través d'unes sessions teòriques i pràctiques, amb l'èmfasi que es mereixen. En aquest article volem donar-vos el marc de referència del nostre treball al CEIP Escola Bellaterra.

\section{INTRODUCCIÓ}

El nostre treball està centrat al 6è curs de primària dins l'àrea de coneixement del medi natural i connecta amb dos dels continguts d'aquesta àrea: la diversitat d'organismes i el treball experimental. Els coneixements previs que hem anat constatant que tenen els nens $i$ les nenes sobre el concepte d'ésser viu i la seva classificació són dispersos i confosos. Això va fer que ens plantegéssim de quina manera podem posar-los en crisi per tal de conduir-los a fer un canvi significatiu en els seus esquemes de coneixement.

La manera de dissenyar les activitats, d'elegir les idees, de connectar amb els seus interessos i de poder arribar a un coneixement adequat del tema va fer prendre la decisió a les mestres, com tantes altres vegades s'ha fet en el CEIP Escola Bellaterra, de demanar l'assessorament i l'ajut d'una persona experta a qui van exposar els dubtes i a partir d'aquí en va sortir un treball de col.laboració que ha durat tres cursos.

Pensem que les escoles han de saber recórrer a aquelles persones, entitats i recursos que tenen a l'abast. A totes les escoles, ben segur, hi ha persones i entitats properes que poden estar disposades a col-laborar. Els mestres i les mestres han de comptar amb elles i saber aprofitar l'enriquiment que poden suposar.

A partir d'aquí es va iniciar, amb el suport dels experts, una programació dels continguts i alhora unes pràctiques que facilitessin la seva adquisició. Això ens ha portat, aquests darrers cursos, a realitzar una unitat didàctica. En el nostre cas es van realitzar les pràctiques en un dels laboratoris de Ciències de l'Educació de la UAB, per la seva proximitat i la seva millor dotació, però es poden fer en qualsevol laboratori escolar si es disposen de lupes binoculars i microscopis. A més a més, donada la relació amb especialistes en microscòpia electrònica de la UAB, se'ns van facilitar la visita guiada al microscopi electrònic d'aquesta universitat.

\section{OBJ ECTIUS}

Els objectius a assolir en aquesta experiència es detallen a continuació:

- Distingir d'una manera raonada els éssers vius dels objectes inanimats. 
- Clarificar el concepte d'ésser viu a través de les seves característiques principals: capacitat de nodrir-se, relacionar-se amb el medi i reproduir-se.

- Tenir clara la classificació dels éssers vius en els cinc regnes: animal, vegetal, fongs, protoctistos i moneres.

- Distingir éssers vius unicel-lulars i pluricel-lulars.

- Identificar les cèl-lules com a components bàsics de tots els éssers vius i conèixer les seves parts principals.

- Introduir-los al món dels microorganismes.

- Despertar interès i curiositat pel món de la ciència.

\section{ELS ÉSSERS VIUS}

1. Les característiques dels éssers vius

2. Què és la cèl.lula?

Teoria cel.lular

Una mica d'història

Com podem veure-la?: Microscòpia

3. Nivells d'organització cel-lular

4. Tipus de cèl-lula

Cèl-lules procariotes

Cèl-lules eucariotes: cèl.lula animal i cèl.lula vegetal

5. Éssers vius unicel-lulars i pluricel-lulars

\section{CLASSIFIQUEM ELS ÉSSERS VIUS}

1. Els cinc regnes

Breu ressenya històrica

La classificació actual

2. Categories taxonòmiques

L'espècie

Nom popular i nom científic

3. Els cinc regnes

Regne Animal

Regne Vegetal

Regne dels Fongs

Regne Protoctista

Regne Monera

4. El món dels microorganismes

Ciència biològica bàsica

Ciència biològica aplicada

Alimentació

Agricultura

Salut

Medi ambient

Figura 1. Contingut de les Sessions teòriques

\section{METODOLOGIA}

Per realitzar aquesta unitat didàctica s'han combinat dues classes teòriques per part de la persona experta en microbiologia, cinc sessions de consolidació de conceptes i de preparació del treball del laboratori amb els i les mestres de l'escola, una sessió pràctica en un laboratori de Ciències de l'Educació de la UAB i una sessió de visita al microscopi electrònic de la UAB.

Les sessions teòriques s'han realitzat en gran grup i les pràctiques en parelles o trios.

El contingut de les classes teòriques està descrit a la figura 1. En la primera sessió es fa una introducció als éssers vius i la segona es dedica a la seva classificació centrant-nos en el món dels microorganismes.

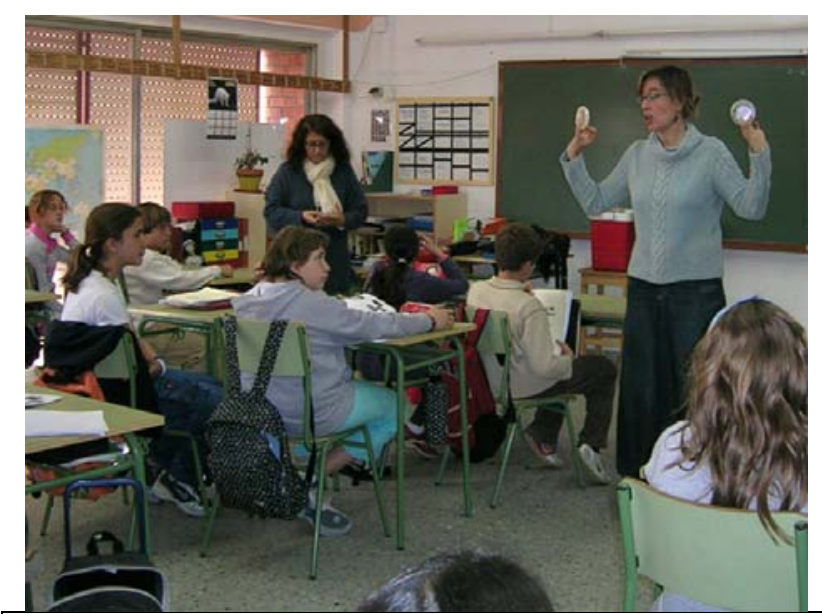

Figura 2. Sessió a l'aula.

Les classes s'acompanyen amb una presentació en suport informàtic (PowerPoint) on es va reflexionant sobre diferents conceptes, a través d'un feedback amb els nens i les nenes (fig. 2). Entre les dues classes teòriques hi ha diferents sessions de consolidació i revisió de conceptes amb els i les mestres de l'escola, utilitzant com a suport el llibre de text.

En l'última sessió preparatòria es recullen mostres per ser observades el dia de les pràctiques de laboratori (fig. 3). Es parteix dels conceptes d'ubiqüitat i diversitat microbiana. Cal tenir present que els microorganismes es troben arreu: al sòl, a l'aire, a l'aigua, a la pols, sobre superfícies, etc. 


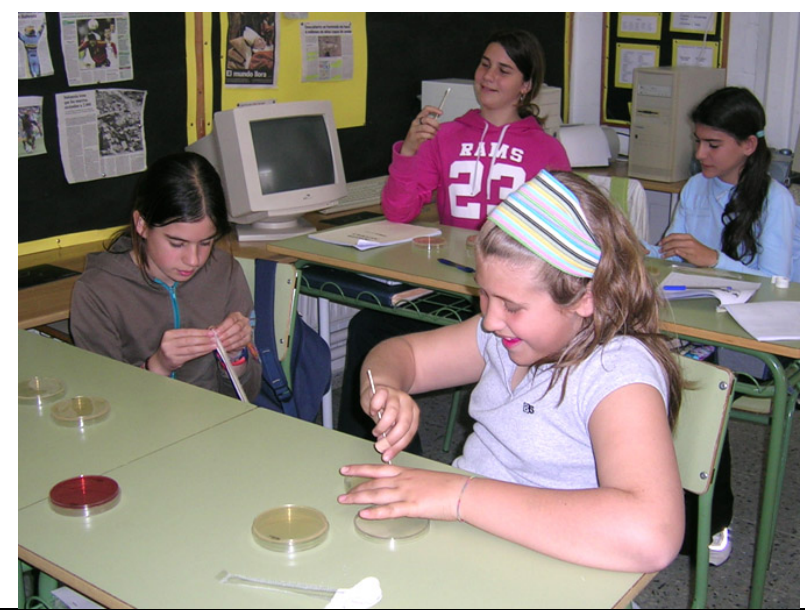

Figura 3. Preparació de mostres per a la sessió de laboratori.

Abans d'anar al laboratori es fa una sessió prèvia per reflexionar i acordar com hauria de ser el treball en un laboratori, a nivell de dinàmica del grup, de les observacions a realitzar i del coneixement del qüestionari que realitzaran per il-lustrar les pràctiques. També es recorda el funcionament i les parts de la lupa binocular i del microscopi òptic.

La classe pràctica de laboratori és una sessió llarga on es realitzen les observacions al microscopi i la lupa binocular (fig. 4).

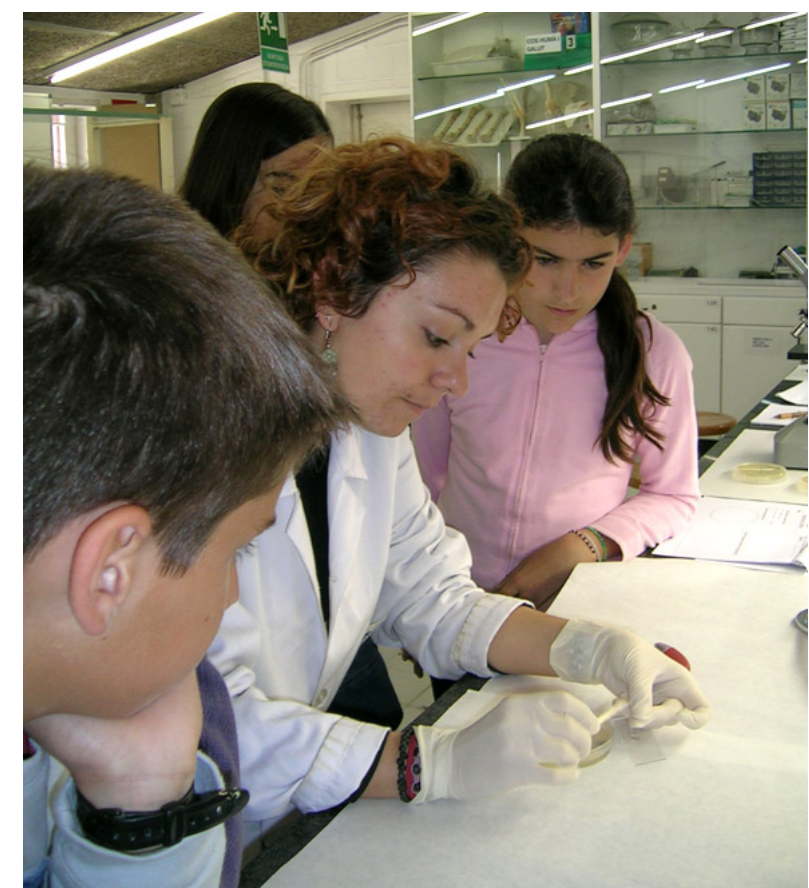

Figura 4. Sessió de laboratori.
Les mostres que s'observen són les preparades per l'alumnat i d'altres que prèviament s'han buscat o s'han preparat. Aquestes poden ser de diferents tipus: mostres d'aigua de procedència diversa, nòduls de lleguminoses, mostres d'aliments com iogurt, formatge, etc., tèrmits, floridures d'aliments com tomàquets, taronges, formatges, pa humit, etc. (preparades a classe amb els nens i les nenes).

Les pràctiques consten d'una sèrie d'activitats dirigides a mostrar diferents formes senzilles d'evidenciar aquest gran món microbià. Un exemple d'aquestes pràctiques és l'observació de floridures. S'ha explicat a les sessions teòriques que estem en contacte constant amb microorganismes, tot i que no en som conscients. A la nevera de casa, quantes vegades hem trobat una peça de fruita florida?

En aquesta activitat es mostren com són les floridures i qui les causa. Es disposa d'aliments que s'han florit degut a unes condicions que ho afavoreixen. Els nens/es fan una observació amb lupes dels diferents tipus de floridures i expliquen en el qüestionari de pràctiques el que veuen.

L'última sessió es dedica a fer una visita al microscopi electrònic de la UAB, per observar la magnitud d'augment que poden oferir aquests aparells.

\section{APRENENTATGES PRÀCTICS}

Amb aquest seguit de sessions pretenem que els nens/es a part d'uns continguts teòrics, aprenguin a:

- Recollir la informació rebuda a l'aula com a inici de la presa d'apunts.

- Buscar informació sobre alguns científics relacionats amb els microorganismes.

- Observar diversos microorganismes presents en la realitat quotidiana.

- Realitzar observacions indirectes d'éssers vius mitjançant fotografies, dibuixos, recursos tecnològics, etc.

- Realitzar observacions directes de microorganismes amb instruments o sense aplicant-hi habilitats i tècniques apreses.

- Adquirir l'hàbit de seguir un ordre a l'hora de fer una experiència.

- Mostrar destresa en la manipulació d'alguns estris de laboratori.

- Ser responsables de la seguretat de les experiències pròpies i col-laborar en la seguretat de les altres persones. 
- Elaborar senzills informes que reflecteixin el treball realitzat al laboratori.

- Comunicar verbalment les observacions fetes o els resultats de les experiències realitzades.

\section{CONCLUSIONS}

D'aquesta experiència duta a terme amb els nens i les nenes de 6è de primària del CEIP Escola Bellaterra de Cerdanyola, durant els cursos 2002-03, 2003-04 i 2004-05, en fem tots plegats una valoració molt satisfactòria.

Les expertes, que alhora som docents universitàries, manifestem que ha estat una experiència enriquidora i molt gratificant.

Les mestres podem assegurar que ha estat fantàstic poder formar-nos d'aquesta manera i gaudir alhora d'estar amb el grup classe fent observacions dels alumnes en una situació d'aprenentatge molt especial.

Els nens i les nenes, cada any, han valorat l'experiència molt positivament $i$ uns quants han manifestat la intenció de voler ser biòlegs quan siguin grans.

\section{AGRAÏMENTS}

Volem agrair a la Facultat de Ciències de l'Educació de la UAB les facilitats donades per realitzar aquesta activitat. També, al Servei de Microscòpia de la UAB per la visita guiada a l'esmentat servei.

\section{BIBLIOGRAFIA D'INTERÈS}

Gaju N., Martínez-Alonso M., Salazar I., Gorina P., Miró L. (2005). Taller: El món dels microorganismes. Llibre de ponències, comunicacions i tallers del VII Simposi sobre l'Ensenyament de les Ciències Naturals.

Generalitat de Catalunya. Departament d'Ensenyament. Currículum Educació Primària

Gorina P., i Rodríguez A. (2002). Aiguaneix 2. Barcanova

Ingraham, J.L. i Ingraham, C.A. (1998). Introducción a la Microbiología. Reverté

Madigan, Martinko i Parker (2003). Brock Biology of microorganisms (10a ed.) Prentice-Hall

Prescott,L.M.,Harley, J.P. \& Klein, D. A. (2004). Microbiologia (5a ed.). McGraw-Hill

\section{WEBS}

\begin{tabular}{l} 
http://edu365.com \\
http://xtec.es \\
\hline http://lacelula.udl.es \\
\hline http:///commtechlab.msu.edu/sites/dlc-me \\
\hline http://www.kidlink.org \\
\hline http://alipso.com/monografias/celula/ \\
\hline http://orbita.starmedia.com/ animalia/celula/celula. \\
htm \\
\hline http://www.biology4kids.com/files/cell main.htm/ \\
\hline http://www.geocities.com/edug2406/celula introduc \\
cion.htm \\
\hline http://es.geocities.com/tonicasany/apuntscell 2.htm \\
\hline I \\
\hline http://www.educationindex.com/award.htm/ \\
\hline http://www.life.uiuc.edu/plantbio/cell| \\
\hline http://edicion-micro.usal.es/web/educativo/micro2 \\
\hline http://www.botany.uwc.ac.za/mirrors/MIT-bio \\
\hline
\end{tabular}

